$\mathbf{R}_{\text {ESEARCH }} \mathbf{P}_{\text {APER }} \longrightarrow \frac{\text { FOOD SCIENCE }}{\text { RESEARCH JOURNAL }}$

e ISSN-2230-9403 - Visit us :

www. researchjournal.co.in

Volume 9 | Issue 1 | April, 2018 | 33-37

DOI : 10.15740/HAS/FSRJ/9.1/33-37

\title{
Awareness of consumers towards the nutritional labelling and health claims disclosed on food label
}

\author{
Ayodhya U. Dudhate and Vijaya M. Nalwade
}

Two hundred consumers from four different professions such as doctor, lawyer, businessman and professor, 50 in each group were selected by purposive random sampling technique. All respondents were interviewed personally to obtain the relevant information. Results showed that all the selected lawyers and doctors and 96 per cent businessmen and professors were vigilant about date of manufacturing and expiry date of the products. Statistical analysis indicated that significantly more per cent of doctors had awareness about MRP, standard marks and list of ingredients than that of businessmen. Also awareness in regard to MRP and standard marks were more in professors as compared to businessmen. Results showed that 84 per cent doctors, 80 per cent businessmen and 70 per cent lawyers and professors used nutrition information given on food label of pre-packaged food while buying the food product. Results inferred that while purchasing the food product more number of businessmen read the content of calories, protein, fat, sugar, vitamins and minerals written on food label. On the other hand, carbohydrate, fibre and sodium content was seen by more per cent of professors. Content of cholesterol was read by more number of doctors compared to other consumers. Results in regard to various health claims written on food label indicated that more number of lawyers had awareness about product suitability for people with diabetes mellitus, cholesterol and heart problem which was significant statistically. On the contrary significantly less per cent of lawyers were aware about the product recommended for balanced diet than that of other consumers.

Key Words : Food label, Consumers awareness, Buying behaviour, Nutrients content, Health claims

How to cite this article : Dudhate, Ayodhya U. and Nalwade, Vijaya M. (2018). Awareness of consumers towards the nutritional labelling and health claims disclosed on food label. Food Sci. Res. J., 9(1): 33-37, DOI : 10.15740/HAS/FSRJ/9.1/33-37. 